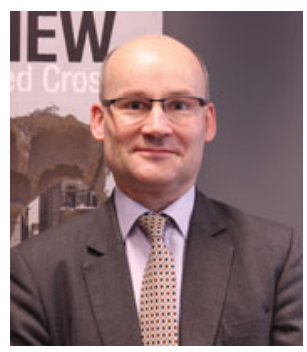

\title{
Announcement: Professor Andrew Thompson joins the Editorial Board of the International Review of the Red Cross
}

The editorial team of the Review is pleased to announce that Professor Andrew Thompson has joined the journal's Editorial Board. Andrew Thompson is the Chief Executive of the UK Arts and Humanities Research Council and Professor of Modern History at the University of Exeter. He joined the University of Exeter in 2011, having previously held a Chair in Imperial and Global History at the University of Leeds where he was Dean of the Faculty of Arts and then Pro-Vice Chancellor for Research.

Professor Thompson is the general editor of the Manchester University Press Studies in Imperialism series, and is currently writing a book for Oxford University Press on the history of the international humanitarian system during and after decolonization. He recently joined the International Center for Humanitarian Affairs organised by the Kenya Red Cross and is the Chair of the Advisory Board of the Institute of Commonwealth Studies at the University of London. 